
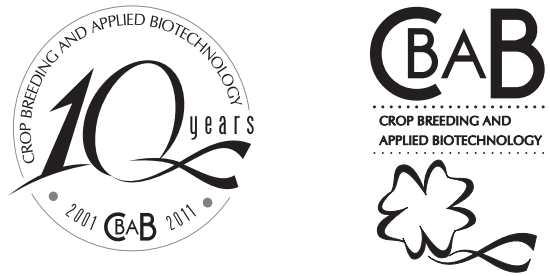

\title{
BRS Japonesa: new sweet cassava cultivar for the Distrito Federal region
}

\author{
Eduardo Alano Vieira ${ }^{1}$, Josefino de Freitas Fialho ${ }^{1}$, Marilia Santos Silva ${ }^{1}$, Silvana Vieira de Paula-Moraes ${ }^{1}$, Charles Martins de \\ Oliveira ${ }^{1}$, José de Ribamar Nazareno dos Anjos ${ }^{1}$, Maria Madalena Rinaidi ${ }^{1}$, Francisco Duarte Fernandes ${ }^{1}$ and Roberto Guimarães \\ Júnior $^{1}$
}

Received 10 August 2010

Accepted 27 November 2010

ABSTRACT - The sweet cassava cultivar BRS Japonesa was selected by the cassava breeding program of Embrapa Cerrados in 25 participatory evaluations conducted in the region of the Distrito Federal, Brazil. The cultivar was well-accepted by producers, and the probability of being ranked among the top four cultivars is $80 \%$.

Key words: Manihot esculenta Crantz; aipim; participatory breeding.

\section{INTRODUCTION}

A main feature of the cassava production in the Federal District (DF) is the predominance of sweet cassava cultivars, with a yellow or cream root-pulp color, for human fresh consumption (cooked, fried, fried balls, among others) (Vieira et al. 2009). Annually, cassava is planted in an area of approximately 850 ha, mainly on small family farms, with an average root yield of $16 \mathrm{tha}^{-1}$. Sweet cassava cultivars, also known as aipins, manioc or tame cassava, are distinguished from the bitter cultivars by low levels of hydrocyanic acid (HCN below 100 ppm) in the roots. This acid is a toxic substance from the hydrolysis of cyanogenic glycosides (mainly linamarin), which can cause poisoning in both humans and animals when consumed in high quantities. Since HCN levels are low in sweet varieties, food use is possible without previous processing.

Most of the cassava production in the Distrito Federal is destined for open-air markets in the DF $(26.40 \%)$ or for small agricultural family industry, where the roots are minimally processed (e.g. peeled, precooked, frozen) $(23.10 \%)$ and the rest is exported to other cities in the region for sale to middlemen, to greengrocers, supermarkets or flour mills, among others. Interestingly, about $6.70 \%$ of the cassava root yield is retained on the farms for family consumption, animal feeding and for the production of homemade cassava flour, contributing to the sustainability of subsistence farming.

The crop has attracted more and more growers in the region, since the consumer market is growing and as a result the profitability of the crop. However, the market is very demanding in terms of the culinary quality of the roots, particularly with regard to the cooking time, which must be less than 30 minutes, the absence of fibers in the roots and their taste. Besides the features listed above, the market of the DF does basically not accept cassava roots unless the root color is cream or yellow, since consumers associate this color with palatability. This preference is interesting, since the more yellow cassava roots are, the higher is the concentrations of beta-carotene, which is

\footnotetext{
${ }^{1}$ Embrapa Cerrados, C.P. 08223, 73.310-970, Planaltina, DF, Brazil. *E-mail: vieiraea@cpac.embrapa.br
} 
directly related to the availability of vitamin A, since betacarotene is the precursor of vitamin A (Iglesias et al. 1997).

In view of the specific market demands of cassava in the DF, the cassava breeding program of Embrapa Cerrados is focused on the development of sweet cultivars with both low HCN levels and high root yield, pest and disease resistance, cooking time under 30 minutes, high culinary quality (flavor, fiber, taste, etc.), roots with yellow rootpulp color, among other characteristics that are important for agronomic and technological aspects. Cassava breeding in Brazil is facilitated by the species' high genetic and phenotypic variability (Ferreira et al. 2008, Nick et al. 2008), which can be used in the generation of new cultivars.

With a view to meet the demand for new alternative sweet cassava cultivars adapted to the regional conditions of the DF, Embrapa Cerrados is releasing the cultivar BRS Japonesa to producers in the region.

\section{SELECTIONMETHODAND CUTLIVAR CHARACTERISTICS}

The sweet cassava cultivar BRS Japonesa was collected at the rural center of Vargem Bonita, in Brasilia (DF), in 1992, and then incorporated into the regional germplasm bank of Cerrado cassava (Banco Regional de Germoplasma de Mandioca do Cerrado - BGMC) as BGMC 751. Because of the outstanding performance in studies of characterization and evaluation of BGMC accessions (Vieira et al. 2008), the cultivar was selected for agronomic evaluation in the DF region.

The method of participatory selection was used to evaluate the cultivar, which is based on an effective participation of farmers in the whole process (HernandezRomero 1992, Fukuda et al. 2006). In the final selection, in addition to the agronomic data, this methodology takes the ranking of preference by farmers/producers into consideration, which reflects the degree of acceptance and, consequently, the probability of use. The accessions that appear most often in top positions are those with highest probability of being used by producers and effectively included in the production process.

The selection process of BRS Japonesa was initiated by the evaluation of eight sweet cassava accessions, including three controls BGMC 753 (IAC 756-70/Japonesinha) BGMC 982 (Iapar 19/Pioneira) and BRS Moura, recommended for cultivation in the DF region. Twenty-five participatory evaluations were conducted in the rural area of the counties Planaltina-DF (14 PP), Cidade Ocidental-GO (8 PP),
Formosa-GO (2 PP), and Padre Bernardo-GO (1 PP), in the growing seasons 2006/2007, 2007/2008 and 2008/2009. Each accession was evaluated in 5-row plots with 10 plants per row, spaced $1.20 \mathrm{~m}$ between rows and 0.80 between plants. Planting was performed between November and December and harvest 12 months after planting. The selection of genotypes for propagation and the cultural practices were according to the recommendations of the cassava production system for the Cerrado region proposed by Souza and Fialho (2003). At harvest at each of the 25 sites of participatory selection, the accessions were classified by the producers in increasing order. The best accession was ranked in position one and the worse in position eight. Aside from the farmers' classification of the accessions in relation to their preference for planting, the following traits were also assessed: i) plant height in $\mathrm{m}(\mathrm{PH})$, ii) total canopy weight in $\mathrm{kg} \mathrm{ha}^{-1}(\mathrm{CW})$, iii) root weight in $\mathrm{kg} \mathrm{ha}^{-1}(\mathrm{RW})$, iv) starch percentage in the roots determined by hydrostatic balance (ST) and v) root cooking time in minutes (CT).

Based on the ranking order, the four best-ranking accessions were BRS Moura, BGMC 753, BGMC 751, and BGMC 982 (Table 1) and that of these, the varieties BGMC 753, BRS Moura and BGMC 982 are already recommended for planting in the DF region, unlike accession BGMC 751. Based on the preference matrix, the cumulative probability of acceptance of accessions was estimated; the probability of preference of BRS Japonesa was $20 \%$ and the chance of being classified in the second, third and fourth position was $40 \%, 72 \%$ and $80 \%$ respectively, according to the producers (Table 2). This good acceptance by producers indicates the potential of accession BGMC 751 for cultivation in the region of the Federal District (DF). This accession present an advantage over the controls (BGMC 753 and BGMC 982), which present cream root-pulp color, since the root-pulp color of this accession is yellow, as of BRS Moura. This characteristic is related to the nutritional quality of the roots, since varieties with yellow pulp are rich in beta carotene, the Vitamin A precursor, and are therefore a functional food.

The cultivar BRS Japonesa is registered by the Serviço Nacional de Proteção de Cultivares under number 26935 and was recommended for the production of sweet cassava. At 25 sites evaluated 12 months after planting, the mean plant traits were determined as follows: plant height was $1.61 \mathrm{~m}$, shoot weight $17924 \mathrm{~kg} \mathrm{ha}^{-1}$, root weight $23575 \mathrm{~kg} \mathrm{ha}^{-1}$, root starch percentage $29.10 \%$ and cooking time $25 \mathrm{~min}$ (Table 3). However, it is important that the root 
BRS Japonesa: new sweet cassava cultivar for the Distrito Federal region

Table 1. Ranking of farmers' preference of eight sweet cassava accessions evaluated in 25 participatory evaluations in the region of the Distrito Federal

\begin{tabular}{|c|c|c|c|c|c|c|c|c|}
\hline \multirow{2}{*}{ Accessions } & \multicolumn{8}{|c|}{ Ranking of preference } \\
\hline & $1^{\circ}$ & $2^{\circ}$ & $3^{\circ}$ & $4^{\circ}$ & $5^{\circ}$ & $6^{\circ}$ & $7^{\circ}$ & $8^{\circ}$ \\
\hline BRS Moura (control) & 9 & 7 & 4 & 2 & 2 & 1 & 0 & 0 \\
\hline BGMC 962 & 0 & 1 & 3 & 5 & 3 & 4 & 4 & 5 \\
\hline BGMC 753 (control) & 9 & 6 & 4 & 5 & 1 & 0 & 0 & 0 \\
\hline BGMC 1118 & 0 & 0 & 1 & 4 & 7 & 6 & 7 & 0 \\
\hline BRS Japonesa & 5 & 5 & 8 & 2 & 3 & 2 & 0 & 0 \\
\hline BGMC 1254 & 0 & 1 & 0 & 0 & 5 & 8 & 10 & 1 \\
\hline BGMC 982 (control) & 2 & 5 & 5 & 7 & 3 & 1 & 1 & 1 \\
\hline BGMC 34 & 0 & 0 & 0 & 0 & 1 & 3 & 3 & 18 \\
\hline
\end{tabular}

Table 2. Accumulated probability of acceptance of eight sweet cassava accessions evaluated in 25 participatory evaluations in the region of the Distrito Federal

\begin{tabular}{|c|c|c|c|c|c|c|c|c|}
\hline \multirow{2}{*}{ Accession } & \multicolumn{8}{|c|}{ Accumulated probability (\%) } \\
\hline & $1^{\circ}$ & $2^{\circ}$ & $3^{\circ}$ & $4^{\circ}$ & $5^{\circ}$ & $6^{\circ}$ & $7^{\circ}$ & $8^{\circ}$ \\
\hline BRS Moura & 36 & 64 & 80 & 88 & 96 & 100 & 100 & 100 \\
\hline BGMC 962 & 0 & 4 & 16 & 36 & 48 & 64 & 80 & 100 \\
\hline BGMC 753 (control) & 36 & 60 & 76 & 96 & 100 & 100 & 100 & 100 \\
\hline BGMC 1118 & 0 & 0 & 4 & 20 & 48 & 72 & 100 & 100 \\
\hline BRS Japonesa & 20 & 40 & 72 & 80 & 92 & 100 & 100 & 100 \\
\hline BGMC 1254 & 0 & 4 & 4 & 4 & 24 & 56 & 96 & 100 \\
\hline BGMC 982 (control) & 8 & 28 & 48 & 76 & 88 & 92 & 96 & 100 \\
\hline BGMC 34 & 0 & 0 & 0 & 0 & 4 & 16 & 28 & 100 \\
\hline
\end{tabular}

Table 3. Mean of the traits plant height in $\mathrm{m}(\mathrm{PH})$, total canopy weight in $\mathrm{kg} \mathrm{ha}^{-1}(\mathrm{CW})$, root yield in $\mathrm{kg} \mathrm{ha}^{-1}(\mathrm{RW})$, starch percentage in roots determined by hydrostatic balance (ST) and cooking time (CT), evaluated in eight sweet cassava accession in 25 participatory evaluations in the region of the Distrito Federal

\begin{tabular}{lccccc}
\hline Accession & PH & CW & RW & ST & CT \\
\hline BGMC 982 (control) & 1.82 & 18134 & 23004 & 29.96 & 24 \\
BGMC 753 (control) & 1.73 & 17660 & 24965 & 28.57 & 26 \\
BRS Moura & 1.41 & 1693 & 22871 & 29.77 & 25 \\
BGMC 34 & 1.88 & 17290 & 18963 & 28.20 & 30 \\
BGMC 1254 & 2.28 & 20287 & 24397 & 27.46 & 27 \\
BRS Japonesa & 1.61 & 17924 & 23575 & 29.10 & 25 \\
BGMC 962 & 1.88 & 22468 & 25387 & 27.64 & 29 \\
BGMC 1118 & 1.47 & 13571 & 21763 & 29.73 & 28 \\
\hline
\end{tabular}

yield of BRS Japonesa ranged from 44375 to $8056 \mathrm{~kg} \mathrm{ha}^{-1}$ and the cooking time ranged from 15 to 30 minutes and the $\mathrm{HCN}$ levels are $15-25 \mathrm{ppm}$ in fresh roots.
The color of the root exterior of BRS Japonesa is light brown, the root cortex cream, the apical leaf color green purplish, the petiole purple, the stem exterior silverish, the terminal are branches green and it is moderately resistant to bacterial blight.

\section{AVAILABILITY OF CASSAVA CUTTINGS}

Embrapa Cerrados is providing farmers who are interested in multiplying the cultivar with cuttings.

\section{ACKNOWLEDGEMENTS}

The authors wish to thank the institutions that supported this research Embrapa, Fundação Banco do Brasil, Conselho Nacional de Desenvolvimento Científico e Tecnológico (CNPq), the program Biodiversity Brazil x Italy and FAPDF. 
EA Vieira et al.

\section{BRS Japonesa: nova cultivar de mandioca de mesa para a região do Distrito Federal}

RESUMO - A cultivar de mandioca de mesa BRS Japonesa foi selecionada pelo programa de melhoramento de mandioca da Embrapa Cerrados em 25 provas participativas conduzidas na região do Distrito Federal. A cultivar revelou elevada aceitação pelos produtores, apresentando $80 \%$ de probabilidade de ser classificada entre as quatro melhores cultivares.

Palavras-chave: Manihot esculenta Crantz; aipim; melhoramento participativo.

\section{REFERENCES}

Ferreira CF, Alves E, Pestana KN, Junghans DT, Kobayashi AK, Santos VJ, Silva RP, Silva PH, Soares E and Fukuda W (2008) Molecular characterization of cassava (Manihot esculenta Crantz) with yellow-orange roots for beta-carotene improvement. Crop Breeding and Applied Genetics 8: 23-29.

Fukuda WMG, Iglesias C, Fukuda C and Caldas RC (2006) Melhoramento participativo. In Sousa LS, Farias ARN, Mattos PLP and Fukuda WMG (eds) Aspectos socioeconômicos e agronômicos da mandioca. Embrapa Mandioca e Fruticultura Tropical, Cruz das Almas, p. 751-780.

Hernandez-Romero LA (1992) Participación de los productores en la evaluación de variedades de yuca. In Hernandez-Romero LA (ed) Memórias de un taller en el CIAT. CIAT, Cali, p. 40-48.
Iglesias C, Mayer J, Chávez AL and Calle F (1997) Genetic potential and stability of carotene content in cassava roots. Euphytica 94: $367-373$.

Nick C, Carvalho M, Assis LHB and Carvalho SP (2008) Genetic dissimilarity in cassava clones determined by multivariate techniques. Crop Breeding and Applied Biotechnology 8: 104-110.

Souza LS and Fialho JF (2003) Sistema de produção de mandioca para a região do cerrado. Embrapa Mandioca e Fruticultura Tropical, Cruz das Almas, 61p.

Vieira EA, Fialho JF, Silva MS, Fukuda WMG and Faleiro FG (2008) Variabilidade genética do banco de germoplasma de mandioca da Embrapa Cerrados acessada por meio de descritores morfológicos. Científica 36: 56-67.

Vieira EA, Fialho JF, Silva MS, Fukuda WMG and Santos Filho MOS (2009) Comportamento de genótipos de mandioca de mesa no Distrito Federal. Ciência Agronômica 40: 113-122. 